\title{
Islam, Asymmetric Policy, and Social Conflict: The State's Role as a Root of Radicalism in the Philippines and Thailand
}

\author{
Bayu Mitra A. Kusuma ${ }^{1}$
}

\begin{abstract}
Radicalism has become a serious problem for many countries, including in Southeast Asia. One of its triggering factors is an extreme understanding of religion that leads to the assumption that people with different understandings are wrong and that violence is a legitimate way to change the situation. This often occurs because of a love of lineage or clan, as well as aggressive instincts. Such an extreme understanding results in the religious social conflicts, which in reality-particularly those involving Islam in Southeast Asia-are often influenced by regimes' asymmetric policies. This study, therefore, explores the role of the State as a root of radicalism in the context of the dynamic relationship between Islam and asymmetric policies, with a focus on the southern Philippines and Thailand. Research findings show that the rise of radicalism in the Philippines was caused by social conflict resulting from government manipulation of referendum policy on special autonomy in predominant Muslim areas. Meanwhile, radicalism in Thailand was triggered by social conflict resulting from the cultural assimilation policy imposed upon the Muslim community by the government.
\end{abstract}

Keywords: Islam, Radicalism, Asymmetric Policy, Social Conflict

\footnotetext{
1 Lecturer at the Department of Islamic Management, Faculty of Da'wah and Communication, and Researcher at the Institute of Southeast Asian Islam (ISAIs), Sunan Kalijaga State Islamic University, Yogyakarta. The previous version of this paper was presented at the Public Lecture organized by the Department of Public Administration, Faculty of Social and Political Sciences, Universitas 17 Agustus 1945 Jakarta on November 15, 2016. Corresponding e-mail: bayu.kusuma@uin-suka.ac.id
} 


\section{Introduction}

Radicalism is a sensitive issue and a serious problem faced by numerous countries worldwide. Generally, radicalism can be interpreted as views or movements that wish for drastic socio-political change or revival, promoted through violence. Radicalism has three rudimentary dimensions. First, a person or a group of people argues that its viewpoint is the most accurate. Second, violence is considered a legitimate means to change a condition. Third, there is active action to change society radically or drastically. In this sense, people can be categorized as radical if they actively support or encourage others to support radical changes that threaten the structures in the society.

Radicalism generally arises from extreme views caused by dissatisfaction with a certain condition. In one perspective, the present increase in radicalism movements or groups "accused" of terrorism can be understood as response to the failure of modernism, liberalism, and democracy, and even philosophy in resolving various crises of modern society (Affandi, 2004, p. 4). The failure of this paradigm, furthermore, has not been followed by the availability of an alternative paradigm that can resolve the crises. As a result, members of society look for their own alternatives in the wrong way and using the wrong understandings. Radicalism, to be sure, is not always related to terrorism. However, it is the foundation for terrorist activities.

This issue adds even more complex problems to societies that are full of conflicts, disputes, and other social problems. As suggested by Ibn Khaldun in his remarkable Muqaddimah, humans possess aggressive behavior because of an "animal power" inside them that drives them to commit acts of violence or torture. Furthermore, some people view it important to "attack before being attacked". This, ultimately, became the reason for the United Stated of America, under President George W. Bush, to invade Iraq and other countries in the Middle East. These invasions were committed by the Bush government under the banner of anti-radicalism and anti-terrorism. However, several other agendas, predominantly economic ones, were also behind the military invasion.

It is undeniable that radical movements also affect the image of religion. This is because many radical actors use religious symbols or jargon. Negative impressions consequently arise, and thus certain religions are discredited. Terms such as Jewish militant, Muslim fundamentalist, or Christian coalition, therefore, reflect international 
political issues with negative connotations (Ahmad, 2001, p. 9). Many people object to the view that religious issues as the trigger of radicalism, an objection that cannot be dismissed since historically radicalism was frequently caused by numerous factors, including poverty, lack of education, legal injustice, and social discrepancy. The actors of radicalism are not always religious ones. However, the impact of these various factors is exacerbated when combined with religious sentiments. As suggested by Geovanie (2013, p. 66), if the dominant factors are likened to dry hay, then religious sentiment can become the lighter that ignites it.

Noting this phenomenon, issues of radicalism becomes even more interesting to be reviewed. Moreover, these issues have not only occurred in the Middle East, but also developed rapidly in South Asia. Bombings in Bali, car bombings in South Thailand, and kidnappings by Abu Sayyaf in the South Philippines are all evidenceand loud alarms-signifying that radicalism has reached areas of Southeast Asia. The question, then, is about states' role in the emergence of radical movements in Southeast Asia. It is whether states fulfill their function to protect their citizens or whether they become root causes of radicalism through asymmetric policies. Based on this concern, it is necessary to investigate the role of the state in the emergence of radicalism in Southeast Asia by emphasizing in the dynamics of Islam, asymmetric policies, and social conflict. This study will not discuss all countries in Southeast Asia, but only the Philippines and Thailand, particularly their southern regions, which are dominated by the Muslim community. The Philippines and Thailand have been selected for study because radicalism has become a major problem in both countries. Violence has become part of everyday news and requires comprehensive resolution.

\section{Literature Review}

\section{Islam and Radicalism}

As explained above, etymologically the word radicalism refers to views or movements that use violence to cause drastic change or socio-political renewal. However, seen in the context of religion, radicalism can be interpreted as religious views that combine fundamentalist understandings of religion with a high degree of religious fanaticism. Holders of such views use violence against others with different view to forcefully actualize their own religious views. 
Violence committed in the name of religion or faith has always been linked to issues of radicalism that lead to terrorism, especially since the Global War on Terror (GWoT) program was enacted by the United States of America in response to the attack on the World Trade Center in New York on 11 September 2001. However, the GWoT has also led to increased Islamophobia, especially in American and European society. Islamophobia is a controversial term often associated with prejudice and discrimination against Muslims (Kusuma, 2016, p. 188). Hasan (2008, p. 12) states that such a fear of Islam has triggered the emergence of anti-Americanism, an attitude shown by radical/fundamentalist groups in response to the anti-fundamentalism shown by America and its allies. The statement by Bush, "you are either with us or with terrorists", is seen as giving these groups no choice but to ally themselves with the latter.

There has been a view or assumption that radicalism and terrorism are interrelated, especially when violence is committed in the name of religion. Islam in particular has become a scapegoat for such blame. However, in this sense, this article assumes that one primary thing must be set right: the term "radical Islam". To the best of researcher's knowledge, the term "radical Islam" is not acceptable, because the essence of Islam brought to the world is rahmatan lil 'alamin or "blessing for the Universe". Based on the word of Allah in QS. Al-Anbiya verse 107: "And We have not sent you (0 Muhammad), except as a mercy to the worlds".

A more appropriate term is "radical Muslims", giving emphasis not to Islam as a religion, but on Muslims as persons or groups who realize Islamic teachings in various ways and through various perspectives. Radical Muslims conduct each way and take each perspective radically, leading to the rise of social conflict in certain areas. This contradicts greatly with the arrival of Islam in Nusantara-the Indonesian archipelago-where Islam was introduced peacefully, not through violence or war. ${ }^{2}$ Seen through the concept of Sunan Kalijaga's serat lokajaya ${ }^{3}$, the arrival of Islam in

\footnotetext{
${ }^{2}$ Nusantara is a term commonly used to describe the archipelago spreading from Sumatra to Papua, most of which is now part of Indonesia. The word Nusantara was first noted in Old Javanese literature to describe the concept of Majapahit Kingdom. Therefore, the term Nusantara refers not only to Indonesia, but to the geographic-anthropologic unity of the islands located between the Asian and Australian continent, including the Malay Peninsula and Temasek.

3 Serat Lokajaya is a document that tells about the repentance of Sunan Kalijaga in front of Sunan Bonang. Before deepening Islam under the direction of Sunan Bonang and later became a member of Walisongo, Sunan Kalijaga is known as the Berandal Lokajaya, a robber who robs from the rich or aristocratic to share with the poor, similar to the legend of the Robin Hood in Britain.
} 
Nusantara can be described in the sentence anglaras ilining banyu, angeli nanging ora keli, (adapting like the flow of the water, immersing but not carried away). Using an adaptive and flexible approach, Islam in Nusantara has developed without causing much conflict. Related to the emergence of radical Muslims in the southern Philippines and Thailand, this study will investigate the relationship between this phenomenon and the policy implemented by the ruling regimes. It will examine whether these policies have been implemented to fulfill egalitarian principles or whether asymmetric ones have aimed to attack or to weaken particular groups.

\section{Asymmetric Policy}

Policy is an activity that is inseparable from human life, both in a micro (individual) context and in a macro (society, nation, and country) context. Thomas Dye suggests the basic definition of public policy is what is done and what is not done by the government (Tangkilisan, 2003, p. 1). Policy can also be defined as action that leads to goals proposed by a person, a group, or government in a certain environment in relation with the existence of certain obstacles while looking for chances to reach desired goals or realize desired targets (Wahab, 2008, pp. 51-52). Shafritz \& Russell (2005, p. 52), in their book Introducing Public Administration, suggest that public policy is everything decided by the government to be or not to be conducted with concern to certain problems, and that public policy is a never-ending process. It can be concluded, therefore, that public policy is everything conducted or not conducted by the government to solve certain problems.

Conceptually, government policy certainly aims at solving problems. However, it is still possible for policy itself to be unwise action that leads to new problems. In more detail, it can be understood in the context of this study that the emergence of religious and social conflict is triggered by public policy that is considered unfair, imbalanced, and disadvantaging a particular group, or, in short, asymmetric. According to the Great Dictionary of the Indonesian Language, "asymmetry" is defined as dissimilarity. Meanwhile, in general asymmetry is defined as inequality or imbalance. Essentially, the concept of asymmetric policy itself does not always have negative connotations. In certain conditions, asymmetric policy is very necessary. For example, in building infrastructure in the capital city rather than rural areas, or in budgeting more for 
human resource development in the areas with dense population than in areas with sparse populations, symmetric policy certainly cannot apply.

On the other hand, asymmetric policy may take a negative meaning if it is implemented to intentionally attack or weaken a certain group by benefiting another group. It is true that, in reality, violence or social conflict related to religion is often influenced by asymmetric policy enacted by the authority of a State. Public policy that should be able to realize social welfare in fact triggers the rise of social conflict, which shows no sign of ending.

\section{Social Conflict}

If policymaking is conducted with an inappropriate asymmetric pattern, it will cause injustice, disadvantage certain groups, and eventually trigger social conflict on a larger scale. Taquiri, in Newstorm \& Davis (1977, p. 11), suggests that conflict is a legacy of social life that may be applicable in different circumstances due to the rise of disagreements, controversies, and conflicts between two or more groups. Galtung (2003, p. 160) adds that conflict is a triangular construction of assumption + behavior + contradiction. It means that conflict is triggered by the assumption of a person or a group of people that influences behavior, in which behavior is contradictory, disparate, and opposed to that of other parties. Conflict may arise since humans have two potentials inside, namely love for the group (identity) and aggression, as suggested by Ibn Khaldun, quoted by Affandi (2004, pp. 81-84).

According to Ibn Khaldun, the fate of humans is to be gifted with love of lineage and community when they are born. This love eventually causes feelings of group pride, loyalty, and of being in the same boat with the community. If it involves many people, it will trigger communal social conflict. Furthermore, humans have aggressive behavior, especially when they feel threatened, because of the existence of animal power, as stated previously. This aggressiveness eventually triggers conflict, both physically and psychologically. However, humans are distinguished from animals because they have minds and thoughts. The combination of aggressive behavior and the feeling of being threatened eventually leads to the rise of radicalism, as in the southern Philippines and Thailand. 


\section{Research Method}

The research employed in this research is qualitative research, using an analytical descriptive approach. Qualitative research is research that results in descriptive data in the form of sentences or spoken utterances from people and behavior that can be observed in detail. Qualitative research concentrates on social study within natural settings. This is helpful for enriching understandings of complexity using various ways, and thus analysis using a qualitative model can provide multi-perspective illustrations (Punch, 2004). The reason the researcher is employing descriptive research in this study is to describe and illustrate the results of the research in sentences, arranged systematically, factually, and accurately, about the facts found and relationships within the phenomenon. In this case, the phenomenon being examined is the dynamic relationship between Islam, asymmetric policy, and social conflict, i.e. the role of the state in the emergence of radicalism.

Data gathering was conducted using several methods. To collect data about the Philippines, a study of literature (academic writings, books, mass media, and others) was used. Meanwhile, to gather data about Thailand, observation, interview, documentation, and literature study were conducted. The data analysis method used in this research is the interactive method (Miles \& Huberman, 1988), consisting of four stages: data collection, data reduction, data display, and drawing a conclusion.

\section{Research Findings}

\section{Mapping Radicalism in Southeast Asia}

Before focusing on the study in the Philippines and Thailand, let us briefly examine the current situation and condition of radicalism in Southeast Asia. In a historical context, threats of extremism and radicalism leading to terrorism have received greater attention from ASEAN since the attacks on the World Trade Center in the United States on 11 September 2001 and the Bali bombings on 12 October 2002 (Emmers, 2003). In Southeast Asia, radicalism is generally affected by both majorityminority relations and heterogeneity in group, race, or religion. The prominence of radicalism in Indonesia, Thailand, and the Philippines can serve as examples. In Indonesia, radical movements have begun to mushroom since the New Order ended and have become increasingly open in their operations, which were previously covert. The issue has been more prominent since the 2002 Bali bombings, which killed 202 
people, and remained subject to discussion through the 2003 Marriot hotel bombing, the 2004 Australian Embassy bombing in Jakarta, and the 2016 Sarinah bombings and shootings. Since the issue of radicalism and terrorism in the country have spread, the chasing of terrorists and the investigation of radical organizations has become more tightly scrutinized. Terrorist networks and radical movements, however, have not been able to be completely eliminated.

The next country is the kin of Indonesia, Malaysia. On the surface, relatively radicalism does not occur. Nevertheless, one area in Malaysia, Sarawak, has been the headquarters of the Daulah Islam Nusantara (DIN), an Islamic group fighting to integrate Sarawak, Sabah, south Philippines, Kalimantan, and Sulawesi. In addition, 40 Malaysians have been recruited by ISIS, and 200 have fought in the Philippines (Hashim, 2015). There is also evidence that Malaysia has become an "exporter" of radical figures. The actions of Noordin Mohd Top and Azahari Husin in Indonesia, for example, are strong evidence of Malaysian influence on radicalism in Southeast Asia. Furthermore, many Malaysians have become trainers at militant camps in the south Philippines. Radicalism in countries such Brunei Darussalam, Vietnam, Cambodia, and Laos, whose populations are homogeneous, in contrast, is relatively minimal. There is almost no news about radicalism in Singapore, either. People there, however, have been grouped by ethnicity; Malay, Chinese, and Indian. While some countries have been able to reduce radicalism, Myanmar is still dealing with violence committed by the government against the Rohingya ethnic group.

The next thing to highlight is the Philippines and Thailand, particularly in the southern part of the countries. The radical groups active in the southern Philippines are the Moro Islamic Liberation Front (MILF) and Abu Sayyaf, which have received great attention from three countries: the Philippines, Indonesia, and Malaysia. With an operation area on territorial waters bordering three countries, Abu Sayyaf has been under oath to Abu Bakar Al-Baghdadi, the highest leader of the Islamic State of Iraq and Syria (ISIS). In southern Thailand, furthermore, we still often hear news about car bomb explosions and violence involving military forces and the locals (Kusuma, 2016, p. 37). Despite differences in view between the Thai government and society, the groups generally accused of radical actions are Barisan Revolusi Nasional (BRN) and Patani United Liberation Organization (PULO). 
How, then, can radicalism be very rooted or grounded in the Philippines and Thailand? There is no bright spot about it. Muslims have undergone many experiences living as both a minority and a majority. One example of Muslims living as a minority is that of Muslims from Mecca who moved to Abyssinia and Madinah (Siddiqi, 2006). Like minority groups in other parts of the world, Muslims in the Philippines and South Thailand are sensitive to conflict based on religious and ethnical background.

\section{The Philippines: After a Controversial Referendum}

In the Philippines, Muslims used to choose peaceful ways to gain the freedom to control their own lives. Along the way, they began to think that constitutional efforts to obtain independence could not be conducted peacefully, considering the condition at that time. Some therefore formed the Moro National Liberation Front (MNLF) under Nur Misuari to organize an armed struggle. At first, the goal of MNLF was to form a sovereign country. This purpose, however, changed when the Philippine government began negotiations with MNLF in 1975. MNLF then began to soften, to discuss, and to compromise. A year later, it agreed upon a conflict solution framework for the southern Philippines.

The agreement, known as the Tripoli agreement, was signed between MNLF and the Philippine government on 23 December 1976. The first point of the agreement is that MNLF receives autonomous administrative divisions for Muslims in the southern Philippines, covering thirteen provinces: Sulu, Basilan, Tawi-Tawi, South Zamboanga, North Zamboanga, South Cotabato, North Cotabato, Manguindanao, Sultan Kudarat, North Lanao, South Lanao, South Davao, and Palawan. Autonomous education and judicial systems were also granted. Defense and international relations, were under the authority of the central government in Manila. The Tripoli agreement caused a serious internal rift in MNLF. Some factions agreed with the agreement, while others disagreed. Some who rejected the agreement formed a new group, the Moro Islamic Liberation Front (MILF). Another more radical and rebellious faction established Abu Sayyaf. Since their establishment, MILF and Abu Sayyaf have been in conflict over their different visions.

After Tripoli agreement, the condition of those living in the thirteen Muslimmajority provinces gradually improved. This, however, did not last long. The agreement, signed in the capital city, Libya was violated by President Ferdinand 
Marcos, who held a referendum in the thirteen provinces listed in the agreement to determine whether their residents agreed or disagreed with it. Before the referendum, the government in Manila moved large amounts of people-mostly Catholics-from the northern Philippines to the south. As such, the once Muslim-majority southern region was taken over by Catholics. This was intentionally meant to ensure that the referendum would have the result Marcos expected, namely, to redirect autonomy from the region to the central government. As a result, there was resistance to the manipulative referendum results from Muslims. Social conflicts, claimed as religious, again emerged. These have continued until the present time.

From the above, it seems that social conflicts involving Muslims in the southern Philippines have been influenced by the asymmetric policy of the Marcos regime. This policy is considered asymmetric because it was intended to weaken the position of the Muslim community and influence the result of the referendum on special autonomy. The resistance turned to radical actions as a symbol of its disappointment, frustration, and lack of trust for the regime and its uneven treatment of them. From this analysis, it can be summarized that the government, or the state, was one root cause of radicalism in the Philippines. In other words, the investigation reveals that the state has been a triggering factor for radical actions in the Philippines.

\section{Thailand: Against Cultural Assimilation}

The next country discussed is Thailand, a country still in grief after the loss of its king, Bhumibol Adulyadej. Southern Thailand, a region that is populated mostly by Muslim Malays and covers Pattani, Yala, Narathiwat, and some parts of Songkhla and Satun, has become sensitive to social conflict. Conflict has occurred since the AngloSiam Treaty was signed in 1909 between the British colonial government in Malaya and the Kingdom of Thailand. This treaty has had a long-lasting impact on the Malay Muslims living in southern Thailand, who face a new culture, language, government, constitution, and environment. Conflict is often triggered by various Thai regimes, which discriminate against the Malay Muslim community. The most discriminative and repressive of these was that of General Phibunsongkhram, which targeted Malay Muslims for cultural assimilation (Mahmud, 2004, p. 2). Since his two periods as head of state, nationalized cultural policy has been the country's main policy. This began with an attempt to apply the Thai language and its culture throughout the country, 
including the southern region. This created confrontation between the Muslim community, which speaks Malay (Kusuma, 2015, p. 11).

The Muslim community in Thailand can be categorized into two groups, namely assimilated and unassimilated. ${ }^{4}$ In their social lives, they are frequently addressed with the inappropriate term khaek, meaning 'outsider' or 'stranger'. Khaek was first used for persons from outside Thailand, but the term gradually became used by the government to describe Muslim Malays in southern Thailand (Aphornsuvan, 2003, p. 5). The Thai government, in this case, has applied a policy of cultural assimilation, which strictly limits the freedom of Muslims in Thailand. The ultimate goal of the policy is Thaification, in which Thai Buddhism serves as the sole identity and culture of the nation. The policy has been conducted through compulsion, intimidation, and threats from the government, particularly the military. It has caused deep culture shock, as the Muslim community in Thailand has had to change its lifestyle drastically and go against its former lifestyle (Kusuma, 2016, p. 112). The social condition has had a heavy and continuous psychological effect on them.

Another regime that greatly discriminated against Muslim Malays, aside from that of Phibunsongkhram, was that of Thaksin Shinawatra, a telecommunication media entrepreneur who became Prime Minister of Thailand in 2001. In dealing with the resistance of the southern Muslim community, the Thai King ordered that a welfare approach be used. Shinawatra, on the other hand, applied a military urgency policy beginning on 5 January 2004. Shinawatra also made several controversial statements: Firstly, that Thai is for those who are Buddhist. Secondly, persons who are not Buddhist must speak Thai. It can be premised, thus, that a Muslim can be called a Thai only if he speaks Thai. Those who are Buddhist, meanwhile, are Thai despite speaking different languages. This asymmetric policy has psychologically caused Thais to have feelings of suspicion towards Muslim Malays.

The conflict in Thailand is closely related to the politics of identity and the creation of conflicts of influence between groups through discriminative policies that

\footnotetext{
${ }^{4}$ Here, the assimilated group is defined as a group that absorbs into the majority population, i.e. Thai Buddhists, in all aspects of life but religion. The unassimilated group, meanwhile, is a group of Muslim citizens who do not blend with Thai Buddhists. They only mingle within their own community in southern Thailand, using the excuse that they must maintain Malay Muslim society in names, language, and customs. Their relations with other communities, therefore, is vulnerable to negative effects.
} 
cause intolerance, violence, and ethnic conflict. Conditions under the Thai regime led to the emergence of groups that sought the independence of Patani, including Barisan Revolusi Nasional (BRN) and the Patani United Liberation Organization (PULO). Those resistance organizations have been labeled as radical and terrorist by the government in Bangkok. We can understand that the emergence of social ethnic and religious conflict in Thailand was triggered by the Thai government's policy of cultural assimilation, which discriminates against the Malay Muslim community and negatively impacts their religious and cultural lives. The asymmetric actions, which disturb the psychology of the Muslim community, have bred resistance and ultimately radical action. It can be concluded that the government or state had an important role as the root cause radicalism in Thailand.

\section{Concluding Remarks}

Radical ideology has been a serious problem for countries in Southeast Asia such as the Philippines and Thailand. This ideology is caused by understanding religion in an extreme way, leading to the assumption that those of different understandings may be attacked and subjected to violence. Such understanding has often generated social conflicts that forefront religion but are in reality often influenced by asymmetric policies from the ruling regime that are meant to weaken other groups, for example Muslims in the southern Philippines and Thailand. In the Philippines, social conflict involving Muslims has been created by Manila policy in which the country socially engineered autonomy in thirteen southern regions by massively mobilizing the people from the northern Philippines, who are Catholics. In Thailand, social conflicts involving religion and ethnicity have been caused by the policy of cultural assimilation assimilated adopted by the government and kingdom, which discriminates against Muslim Malays in their religious and cultural lives. It can be surmised, thus, that the government may have an important role in causing radicalism, as found in the Philippines and Thailand.

To end radicalism in the Philippines and south Thailand, they must cease their practice of discrimination and to stop implementing asymmetric policies that subjugate particular groups. Furthermore, these countries must continue to improve the welfare of their populations. When a country is able to be fair to all society, without considering their religious or ethnic backgrounds, and able to improve the wellbeing 
of its citizens, radicalism can also be reduced. In a broader scope, if we refer to one of the three concepts of ASEAN society-i.e. political security community-the stability of Southeast Asia is the responsibility of all countries. Each country in Southeast Asia should work together to handle regional security problems, including radicalism.

\section{References}

Affandi, H.I. (2004). Akar Konflik Sepanjang Zaman: Elaborasi Pemikiran Ibn Khaldun. Yogyakarta: Pustaka Pelajar.

Ahmad, N. (2001). Pluralitas Agama: Kerukunan dalam Keragaman. Jakarta: Penerbit Kompas.

Aphornsuvan, T. (2003). History and Politics of the Muslims in Thailand. Bangkok: Thammasat University.

Emmers, R. (2003). ASEAN and the Securitization of Transnational Crime in Southeast Asia. The Pacific Review, 16(4).

Galtung, J. (2003). Studi Perdamaian: Perdamaian dan Konflik, Pembangunan dan Peradaban. Surabaya: Pustaka Eureka.

Geovanie, J. (2013). Civil Religion: Dimensi Sosial Politik Islam. Jakarta: Gramedia Pustaka Utama.

Hasan, N. (2008). Laskar Jihad: Islam, Militansi, dan Pencarian Identitas di Indonesia Pasca Orde Baru. Jakarta: LP3ES.

Hashim, A.S. (2015). The Impact of the Islamic State in Asia: Policy Report. Singapore: S. Rajaratnam School of International Studies, Nanyang Technological University.

Kusuma, B.M.A. (2016). Masyarakat Muslim Thailand dan Dampak Psikologis Kebijakan Asimilasi Budaya. Hisbah: Jurnal Bimbingan dan Konseling Islam, 13(1), 112.

. (2016). Mereduksi Islamofobia Melalui Aksi Nyata Lintas Iman. In Kusuma, B.M.A. \& Musyirifin, Z. (Eds.), Keberpihakan dan Kepedulian Lintas Iman untuk Difabel. Yogyakarta: Interfidei.

. \& Octastefani, T. (2016). Pattani United Liberation Organization: From Jihad to Local Politics Movement. The Indonesian Journal of Public Administration, 2(1), 37. 
. (2015, October 27-30). Dialectics of Islam, Politics and Government in Southeast Asian Countries: A Comparison of Indonesia and Thailand. Paper presented at the 6th Graduate School of UIN Sunan Kalijaga - Faculty of Philosophy, George August University of Gottingen, Joint International Conference on Islamic Studies Revisited, Yogyakarta.

Mahmud, N.A.N. (2004). Sejarah Perjuangan Melayu Patani 1885-1954. Negeri Sembilan: Saremban.

Miles, M.B. \& Huberman, M.A. (1998). Qualitative Data Analysis: A Source Book of New Methods. London: Sage Publication.

Newstorm, J.W. \& Davis, K.E. (1977). Human Behavior at Work: Organizational Behavior. Singapore: McGraw-Hill.

Punch, K.F. (2004). Introduction to Social Research: Qualitative and Quantitative Approach. 2nd Edition. London: Sage Publication.

Shafritz, J.M. \& Russel, E.W. (2005). Introducing Public Administration. New Jersey: Pearson Education.

Siddiqi, M.Y.M. (2006). The Prophet Muhammad SAW: A Role Model for Muslim Minorities. Leicestershire: The Islamic Foundation.

Tangkilisan, H.N.S. (2003). Kebijakan Publik yang Membumi: Konsep, Strategi, dan Kasus. Yogyakarta: Yayasan Pembaruan Administrasi Publik Indonesia \& Lukman Ofset.

Wahab, S. A. (2008). Pengantar Analisis Kebijakan Publik. Malang: UMM Press. 